\title{
De facto and de jure Crown Sovereignty: Reconciliation and Legitimation at the Supreme Court of Canada
}

\author{
Ryan Beaton ${ }^{\star}$
}

\section{Introduction}

This paper offers a short story of Crown sovereignty at the Supreme Court Canada in order to shed light on questions the Court has raised about the legitimacy of Crown sovereignty over territory claimed by First Nations. In skeletal form, the story is simple. The Crown - first Imperial British and later Canadian federal and provincial - asserted sovereignty over what is now Canadian territory, and Canadian courts (and the Judicial Committee of the Privy Council) accepted those assertions without question. Yet the Supreme Court of Canada has lately qualified Crown sovereignty in striking ways, perhaps most notably in speaking of "de facto Crown sovereignty" in reasons released in $2004 .{ }^{1}$ The purpose behind this qualification, in line with the Court's Aboriginal rights and title cases since Calder $v$ British Columbia (Attorney General), ${ }^{2}$ seems to be to encourage the Crown to negotiate modern treaties and settle outstanding Aboriginal rights and title claims in order to perfect or legitimate Crown sovereignty. ${ }^{3}$ As Crown negotiations with First Nations stalled, however, the Court proceeded to develop its own framework for the procedural legitimation of Crown sovereignty, i.e. a framework of procedural safeguards designed to weed out "bad" exercises of Crown sovereignty from legitimate ones.

This background story helps clarify the legal significance and function of the Court's reference to the Crown's de facto sovereignty. In particular, as explained below, when the Court speaks of de facto sovereignty, this is not a simple reference to the factual issue of who may be, or may have been, exercising authority - having effective control, capable of enforcing laws on the ground in a given place at a given time. ${ }^{4}$ Rather, in the broader context of its case law on assertions of Crown sovereignty and Aboriginal title, the Court's reference to de facto Crown sovereignty functions somewhat like a suspended declaration of invalidity in cases where a court concludes that legislation is unconstitutional, but grants Parliament or the relevant legislature time to repair the law. In such cases, the court declares that the legislation will be treated as though it were valid law (perhaps granting constitutional exemptions in individual cases). ${ }^{5}$ Similarly, the Court's reference to de facto Crown sovereignty signals two key points: (1) the Court is questioning, at a minimum, the legitimacy, or the de jure quality, of Crown sovereignty; and (2) the Court intends nonetheless to treat Crown assertions of sovereignty as though they were legally valid, while providing the Crown (including Parliament and provincial legislatures $)^{6}$ time and guidance to perfect those assertions.

Below, I expand on the background story summarized above in order to clarify the function and significance of the Court's reference to the Crown's de facto sovereignty and similar terms. The takeaway is that the Court, over the past few decades, has shifted away from a backward-looking substantive justification of Crown sovereignty towards a forward-looking procedural legitimation. That is, the Court has 
now explicitly rejected the racist doctrines that historically underpinned claims that the Crown acquired sovereignty, through mere assertion, over First Nations territories and peoples. These substantive justifications of Crown sovereignty included the doctrine of terra nullius and related doctrines of a hierarchy of civilizations, according to which First Nations lacked the capacity to own land or exercise sovereignty. At the same time, the Court has framed its modern case law on Aboriginal and treaty rights with the stated purpose of reconciling "the pre-existence of aboriginal societies with the sovereignty of the Crown."' The Court's broad aim under section 35 of the Constitution Act, $1982,{ }^{8}$ has been to chart a path towards the legitimation of Crown sovereignty through a combination of urging the Crown to negotiate modern treaties and imposing procedural constraints on exercises of Crown sovereignty that impact Aboriginal interests pending final negotiated settlements.

\section{Crown Sovereignty at the Supreme Court of Canada}

It should come as no surprise that the Supreme Court of Canada has long accepted sovereign claims made by the Crown. The default position for domestic courts in other common law settler states has traditionally been that a court cannot adjudicate the sovereign claims of the state that established it. Thus, in Johnson $v$ M'Intosh, ${ }^{9}$ Chief Justice John Marshall of the United States Supreme Court rejected the notion that US courts might question the legitimacy of sovereign claims made by the US:

\footnotetext{
We will not enter into the controversy, whether agriculturists, merchants, and manufacturers, have a right, on abstract principles, to expel hunters from the territory they possess, or to contract their limits. Conquest gives a title which the courts of the conqueror cannot deny, whatever the private and speculative opinions of individuals may be, respecting the original justice of the claim which has been successfully asserted.... It is not for the courts of this country to question the validity of this title, or to sustain one which is incompatible with it. ${ }^{10}$
}

Similarly, in Coev Common Wealth of Australia ${ }^{11}$ Justice Jacobs of the High Court of Australia stated that a challenge to a nation's sovereignty was "not cognisable in a court exercising jurisdiction under that sovereignty which is sought to be challenged." ${ }^{2}$

The Supreme Court of Canada has often positioned itself along the same track. For instance, in $R v$ Sparrow, ${ }^{13}$ the Court offered the following unequivocal statement, citing Chief Justice Marshall's reasons in M'Intosh:

It is worth recalling that while British policy towards the native population was based on respect for their right to occupy their traditional lands, a proposition to which the Royal Proclamation of 1763 bears witness, there was from the outset never any doubt that sovereignty and legislative power, and indeed the underlying title, to such lands vested in the Crown. ${ }^{14}$

Yet in the same set of reasons, the Court seemed to signal a radically different tack, quoting with approval the words of Professor Noel Lyon: "Section 35 calls for a just settlement for aboriginal peoples. It renounces the old rules of the game under which the Crown established courts of law and denied those courts the authority to question sovereign claims made by the Crown." ${ }^{15}$ Building on this rationale in Taku River Tlingit First Nation $v$ British Columbia (Project Assessment Director), ${ }^{16}$ the Court offered a striking qualification of Crown sovereignty by pointedly stating that "[t]he purpose of s. 35(1) of the Constitution Act, 1982 is to facilitate the ultimate reconciliation of prior Aboriginal occupation with de facto Crown sovereignty." ${ }^{17}$

That said, the ambivalence expressed by the Court in Sparrow reappears in similar form in the Court's 2014 reasons in Tsilhqot'in Nation v British Columbia. ${ }^{18}$ In the same paragraph, the Court states that "the doctrine of terra nullius (that no one owned the land prior to European assertion of sovereignty) never applied in Canada, as confirmed by the Royal Proclamation of 1763" but nonetheless that "[a]t the time of assertion of European sovereignty, the Crown acquired radical or underlying title to all the land in the province [of British Columbia]."19 
The Court here seems to understand the doctrine of terra nullius in the strict sense of a doctrine that denies any pre-existing legal rights in the land - in which case the Court can, without contradiction, reject the application of terra nullius while at the same time accept that the Crown acquired underlying title to, and sovereignty over, all the land in British Columbia through mere assertion of sovereignty. The position is then that there exist some legal rights in the land that predate the Crown's assertion of sovereignty, but that these rights are in some sense too weak to prevent the Crown's acquisition - through assertion, and even in the absence of treaty-making or conquest - of sovereignty and underlying title. And this is precisely what the Court had stated in Delgamuukw $v$ British Columbia,${ }^{20}$ concluding that "aboriginal title crystallized" as a burden on underlying Crown title "at the time sovereignty was asserted." 21

Put this way, however, it is clear that this conception of Aboriginal rights relies, if not on terra nullius, then on some attenuated doctrine of a hierarchy of civilizations, or at least a hierarchy of legal systems. How else could the Crown acquire sovereignty over, and underlying title to, Indigenous territories through mere assertion, in the face of "pre-existing systems of aboriginal law"22 that did not recognize the Crown's acquisition of sovereignty and underlying title? If the Crown acquired sovereignty and underlying title by assertion, in the absence of treaty or conquest, then it follows that the Crown displaced pre-existing systems of Aboriginal law - at least on fundamental questions of sovereignty and underlying title - by mere assertion. To accept that conclusion, in such a manner that it would ground de jure Crown sovereignty, we must accept that the legal system asserted by the Crown is in some sense superior to pre-existing systems of Aboriginal law - a view that, historically at least, is grounded in doctrines of civilizational hierarchy that rank Indigenous societies as less advanced than those of their European colonizers.

In this respect, it is worth noting that the Supreme Court has rejected not only terra nullius, but also earlier judicial acceptance of doctrines of civilizational hierarchy. In Simon $v$ The Queen, ${ }^{23}$ for instance, the Court expressly rejected the view that Aboriginal peoples lacked the capacity to enter binding treaties. ${ }^{24}$ The Court in Simon noted that the Nova Scotia Court of Appeal ${ }^{25}$ had agreed with statements of Justice Patterson in $R$ $v$ Syliboy, ${ }^{26}$ explaining why Indigenous peoples lacked the capacity to enter into treaties. Justice Patterson had concluded that "the Indians of Nova Scotia" did not have "status to enter into a treaty", explaining that conclusion by stating, in part, that "[a] civilized nation first discovering a country of uncivilized people or savages held such country as its own until such time as by treaty it was transferred to some other civilized nation. The savages' rights of sovereignty even of ownership were never recognized."27

In Simon, Chief Justice Dickson quoted these words of Justice Patterson, finding that they "reflect[ed] the biases and prejudices of another era in our history" and that "[s]uch language is no longer acceptable in Canadian law". ${ }^{28}$ As a result, Chief Justice Dickson rejected Justice Patterson's conclusions on the capacity of Indigenous peoples to enter treaties: "With regard to the substance of Justice Patterson's words, leaving aside for the moment the question of whether treaties are international-type documents, his conclusions on capacity are not convincing." ${ }^{29}$ Chief Justice Dickson concluded that " $[\mathrm{t}]$ he Micmac Chief and the three other Micmac signatories, as delegates of the Micmac people, would have possessed full capacity to enter into a binding treaty on behalf of the Micmac." 30

In sum, the Supreme Court of Canada has taken several noteworthy steps to underscore that the Crown has a sovereign legitimacy problem. The discussion above highlights three in particular. The Court has: (1) claimed the authority to question sovereign claims made by the Crown; (2) qualified Crown sovereignty in various ways, notably by speaking of "de facto Crown sovereignty"; and (3) explicitly rejected doctrines traditionally relied upon to justify the Crown's acquisition of sovereignty through assertion.

At the same time, the Court has consistently reaffirmed the Crown's acquisition of sovereignty and underlying title from the moment of sover- 
eignty assertion. In so doing, the Court is not simply making historical or empirical claims. The Court is upholding the Crown's legal power to exercise sovereignty over unceded territory, despite the questions the Court has itself raised about the legitimacy of Crown sovereignty.

\section{Unpacking the Court's Qualifications of Crown} Sovereignty

How, then, should we describe the function and significance of the Court qualifying Crown sovereignty in the way it has? As already suggested, we might say that the Court has raised questions about the legitimacy of Crown sovereignty in the absence of treaties, while continuing to uphold the legality of Crown sovereignty. In this sense, then, we can draw a rough analogy to a suspended declaration of invalidity in the case of legislation that the Court finds unconstitutional but continues to enforce in law. ${ }^{31}$ The Court's case law under section 35 does, however, show an increasing sense of urgency regarding the gap between the legitimacy and legality of Crown sovereignty.

The Court first addressed this gap between legitimacy and legality in Sparrow, framing the gap in terms of a collision between the federal power "to legislate with respect to Indians pursuant to s. 91(24) of the Constitution Act, 1867" and the federal duty under section 35(1) of the Constitution Act, 1982. ${ }^{32}$ The Court's response to the collision in Sparrow set the course for its response in all subsequent section 35 cases. Broadly speaking, there are two prongs to the Court's response: (i) declaring an increasingly stringent duty on the Crown to reach negotiated settlements, while (ii) imposing procedural constraints on exercises of Crown sovereignty, as a kind of stopgap legitimation measure, pending final settlement of treaties. ${ }^{33}$

In particular, the Court stated in Sparrow that the most promising way to reconcile conflicts between federal power and federal duty is to require the Crown to justify any infringement or denial of Aboriginal rights. ${ }^{34}$ In cases of dis- agreement as to whether the Crown can justify proposed infringements or denials, the parties may ask the courts to settle the issue. This establishes a form of judicially mediated Crown sovereignty - the courts weeding out illegitimate exercises of Crown sovereignty, while allowing legitimate ones, pending negotiated solutions.

In one sense, there is nothing unusual in the courts reviewing state action for violations of constitutional rights. That is par for the course in a system of judicial supremacy. As far as rights under the Canadian Charter of Rights and Freedoms ${ }^{35}$ are concerned, section 1 of the Charter explicitly calls for the courts to distinguish justifiable from non-justifiable infringements. However, the doubts the Court have raised regarding the legitimacy of Crown sovereignty in the context of outstanding Aboriginal rights and title claims are what make the section 35 context unique. For the Court has framed the overarching purpose of section 35 not simply in terms of protecting constitutional rights, but rather, as noted above, in terms of reconciling "the pre-existence of aboriginal societies with the sovereignty of the Crown." ${ }^{36}$ Thus the judicial protection of section 35 rights, particularly the procedural safeguards discussed below, are designed to promote the overarching goal of reconciliation, understood as the legitimation of Crown sovereignty through negotiated settlement of outstanding claims.

The following two sections retrace how the Court has developed the two-pronged approach first laid down in Sparrow, ratcheting up the strictness of the Crown duty to negotiate and multiplying the procedural safeguards for claimed but still "unproven" section 35 rights.

\section{The Court urges the Crown to negotiate}

The Court's characterization of the Crown duty to negotiate has moved steadily from a duty grounded in morality, to one grounded in the honour of the Crown, to one grounded squarely in law. In 1997, the Court issued its reasons in Delgamuukw, with a majority of the Court concluding that Aboriginal title had not been extin- 
guished in British Columbia following assertion of Crown sovereignty and that it now received constitutional protection under section 35 of the Constitution Act, 1982. ${ }^{37}$ However, for technical reasons relating to the original form of pleadings, the Court refrained from declaring that the Delgamuukw plaintiffs had Aboriginal title to the land they claimed. ${ }^{38}$ The Court thus combined judicial restraint in ordering a new trial with pressure on the Crown to negotiate in light of the Court's broader conclusion that Aboriginal title had not generally been extinguished in British Columbia. Citing Sparrow, Chief Justice Lamer added that the Crown had a "moral, if not a legal, duty to enter into and conduct [...] negotiations in good faith", with the Court acting in a supporting role through its judgments. ${ }^{39}$

The language of "moral duty" was adopted three years later by the chambers judge in Haida, a case in which the Crown had replaced tree farm licences on territory claimed by the Haida Nation without consulting the Haida. At issue was whether the Crown had a duty to consult with the Haida about the decision to replace the licences. Although such a focused duty of consultation is considerably narrower than the duty to negotiate that was at issue in Delgamuukw, the chambers judge in Haida drew on Delgamuukw to conclude that the Crown had only a moral duty to consult:

In the circumstances, I conclude that the Crown does have a moral duty to consult with the Haida concerning their Aboriginal claims, in connection with the decision to replace T.F.L. 39. In Delgamuukw supra, in the context of encouraging the parties to settle their dispute by negotiation, Lamer, C.J.C. said this at paragraph 186: "Moreover, the Crown is under a moral, if not a legal, duty to enter into and conduct those negotiations in good faith." I think that statement also applies to this case. ${ }^{40}$

The Supreme Court of Canada went further on appeal, agreeing with the British Columbia Court of Appeal that the "government has a legal duty to consult with the Haida people." 11 The Court added, more broadly, that the Crown also had a duty to enter into treaty negotiations, though it avoided any explicit characterization of this broader duty as either moral or legal, stating instead that "the honour of the Crown requires negotiations leading to a just settlement of Aboriginal claims." 42 The Court then linked this duty to negotiate to the overarching purpose of section 35 by underscoring that " $\mathrm{t}$ ] reaties serve to reconcile pre-existing Aboriginal sovereignty with assumed Crown sovereignty, and to define Aboriginal rights guaranteed by section 35 of the Constitution Act, 1982." ${ }^{43}$

The Court in Haida also explained how the duty to negotiate and the duty to consult were distinct yet related, with the duty to consult protecting those interests that are subject to negotiation while negotiations are ongoing. In particular, the Court stated that where treaties have yet to be concluded, the honour of the Crown requires the Crown "to participate in processes of negotiation. While this process continues, the honour of the Crown may require it to consult and, where indicated, accommodate Aboriginal interests." 44

At issue in Haida was the split between the chambers judge and Court of Appeal about whether to characterize as "moral" or "legal" the narrower Crown duty to consult the Haida on its decision to replace a tree farm licence. One can only assume the Supreme Court made a deliberate choice to avoid explicitly characterizing the broader duty to negotiate treaties as either "moral" or "legal", opting instead to ground this broader duty in the honour of the Crown. However, a decade later, the Court offered this gloss in Tsilhqot'in: "The Court in Haida stated that the Crown had not only a moral duty, but a legal duty to negotiate in good faith to resolve land claims... The governing ethos is not one of competing interests but of reconciliation." ${ }^{45}$ Both the narrower Crown duty to consult First Nations pending comprehensive negotiated settlements and the broader duty to pursue negotiations towards such settlements are now clearly characterized by the Court as legal duties.

Over the quarter century from Sparrow to Tsilhqot'in, the Court has thus steadily ratcheted up the urgency of its calls for the Crown to negotiate treaties where treaties have yet to be concluded - that is, where questions are most 
pressing about the legitimacy of "de facto" or "assumed" Crown sovereignty. Against the background of this case law, then, the primary function of these striking qualifications of Crown sovereignty is to signal to the Crown an urgency to repair the questionable foundations of its sovereign claims, at least where treaties are lacking.

\section{The Court imposes procedural constraints on the Crown}

Given the slow pace of treaty negotiations, many First Nations began turning to the courts for protection of rights they asserted but that had not yet been secured in treaties or recognized by courts. To address these concerns, the Court in Haida developed the Crown duty of consultation and accommodation. This duty serves to protect Aboriginal interests that were the subject of asserted rights, such that " $\mathrm{t}]$ he Crown, acting honourably, cannot cavalierly run roughshod over Aboriginal interests where claims affecting these interests are being seriously pursued in the process of treaty negotiation and proof." 46 The Court distinguished the Crown fiduciary duty, applicable to established Aboriginal legal interests, from the Crown duty to consult, applicable to asserted but unproven interests. ${ }^{47}$

As a result of the procedural protections developed in Haida, the courts are now positioned to review exercises of Crown sovereignty that affect Aboriginal interests subject to asserted rights, as well as exercises of Crown sovereignty that infringe established Aboriginal and treaty rights. In the specific context of Aboriginal title, the Court in Tsilhqot'in recently explained in detail the current state of the law on Crown obligations under the duty to consult and accommodate, and under the Crown fiduciary duty. ${ }^{48}$ In particular, the Court stressed that where title is claimed but not yet established, the Crown has only a procedural duty "to consult and, if appropriate, accommodate the unproven Aboriginal interest." ${ }^{\prime 9}$ This statement would apply equally to Aboriginal rights other than title.

Since Haida, the courts have developed considerable case law on the procedural obligations that constrain Crown exercises of sovereignty in the face of outstanding Aboriginal rights and title claims. For instance, the Court has held that the duty to consult is "not confined to decisions or conduct which have an immediate impact on lands and resources" but rather "extends to 'strategic, higher level decisions' that may have an impact on Aboriginal claims and rights". ${ }^{50}$ The Court has also held that the duty to consult applies where the Crown exercises a power granted to it by treaty. ${ }^{51}$ The Court has explained that, given the collective nature of Aboriginal rights, the duty to consult is in each case owed to the appropriate collective, and the Court has given some consideration to circumstances in which individuals might have standing to assert a breach of the duty to consult. ${ }^{52}$ The Court has held that the Crown duty to consult may, in certain circumstances, be discharged by an administrative tribunal such as the National Energy Board. ${ }^{53}$

Indeed, the Crown duty to consult, introduced in Haida to address situations in which Aboriginal rights were asserted but not yet established, may be displacing the Crown fiduciary duty as the Court's preferred frame of analysis even in cases of established section 35 rights. In Clyde River (Hamlet) v Petroleum Geo-Services $I n c,{ }^{54}$ for instance, the Court repeatedly stressed the fact that the case involved established treaty rights, ${ }^{55}$ yet incorporated this fact within its analysis of the Crown's duty to consult, never mentioning the Crown fiduciary duty. This development is cause for concern for section 35 rights-holders, as the Court has repeatedly insisted that the duty to consult imposes no duty on the Crown to reach an agreement on the necessary scope of consultation with those asserting rights; the Crown may act in the face of disagreement. ${ }^{56}$ The power of the Crown to act in the face of disagreement as to the scope of its procedural duties under section 35 in turn raises questions about how effective the imposition of such duties can be in encouraging the Crown to pursue treaty negotiations in earnest. That said, a critique of the Court's section 35 is beyond the scope of this paper; the intention here has been simply to describe that framework as it currently exists. 


\section{Conclusion}

The procedural duties imposed on the Crown under section 35 are framed by the Court's stated purpose for that section: "to facilitate the ultimate reconciliation of prior Aboriginal occupation with de facto Crown sovereignty." 57 Such "ultimate reconciliation" would, presumably, mean also the legitimation of Crown sovereignty, i.e. the perfection of Crown assertions of sovereignty. To that end, the Court has repeatedly urged the Crown, in increasingly strict terms, to negotiate treaties with First Nations who have yet to conclude them. In the meantime, the Court will impose procedural obligations on the Crown where proposed state action could negatively impact Aboriginal interests subject to asserted rights. The promise seems to be that this judicial filter will allow only legitimate, or "honourable," exercises of Crown sovereignty to pass, as we await "ultimate reconciliation" and legitimation of Crown sovereignty.

This regime of judicial review could be characterized as one of judicially mediated Crown sovereignty or as a procedural legitimation of Crown sovereignty. The Court has designed this regime with the stated aim of supporting the Crown in perfecting its assertions of sovereignty. In other words, the Court's aim is to assist the Crown in repairing or establishing legitimate foundations for its assertions of sovereignty in Canada. In the meantime, the Court's repeated qualifications of Crown sovereignty by such terms as "de facto" and "assumed" signal that the Court has to some degree withdrawn the legitimacy of Crown sovereignty, while nonetheless upholding its legality. In practical terms, this means that the courts will continue to enforce exercises of Crown sovereignty that infringe Aboriginal interests, subject to judicial review for an expanding list of procedural safeguards.

\section{Endnotes}

* $\mathrm{PhD}$ candidate in the Faculty of Law at the University of Victoria, 2017 Trudeau Foundation Scholar.
1 Taku River Tlingit First Nation v British Columbia (Project Assessment Director), 2004 SCC 74 at para 42, [2004] 3 SCR 550 [Taku River].

2 [1973] SCR 313, 34 DLR ( $\left.3^{\text {rd }}\right) 145$ [Calder].

3 As Chief Justice Lamer summed up the Court's preference for negotiation over litigation in Delgamuukw v British Columbia, [1997] 3 SCR 1010 at $1123,153 \operatorname{DLR}\left(4^{\text {th }}\right) 193$ [Delgamuukw]: "As was said in Sparrow, at p. 1105, s. 35(1) 'provides a solid constitutional base upon which subsequent negotiations can take place'. Those negotiations should also include other aboriginal nations which have a stake in the territory claimed. Moreover, the Crown is under a moral, if not a legal, duty to enter into and conduct those negotiations in good faith. Ultimately, it is through negotiated settlements, with good faith and give and take on all sides, reinforced by the judgments of this Court, that we will achieve what I stated in Van der Peet, supra, at para. 31 , to be a basic purpose of s. 35(1) - the reconciliation of the pre-existence of aboriginal societies with the sovereignty of the Crown'. Let us face it, we are all here to stay." As I explain later in this paper, the Court has more recently stated that the Crown has not only a moral duty but a legal duty to enter into and conduct treaty negotiations in good faith.

4 Of course, the Court does at times have the factual issue in mind when using "de facto" in this context, as in the following statement from Haida Nation $v$ British Columbia (Minister of Forests), 2004 SCC 73 at para 32, [2004] 3 SCR 511 [Haida]: "This process of reconciliation flows from the Crown's duty of honourable dealing toward Aboriginal peoples, which arises in turn from the Crown's assertion of sovereignty over an Aboriginal people and de facto control of land and resources that were formerly in the control of that people." My argument is that the Court's use of de facto Crown sovereignty and similar terms also functions more broadly to signal that the Court will continue to enforce the legality of exercises of Crown sovereignty, even though it is to some degree questioning their legitimacy.

5 For a recent example of the Court issuing a suspended declaration of invalidity and discussing constitutional exemptions, see Carter $v$ Canada (Attorney General), 2015 SCC 5, [2015] 1 SCR 331.

6 Throughout this paper, I will use "Crown" broadly to include Parliament and provincial legislatures.

$7 \quad R v$ Van der Peet, [1996] 2 SCR 507 at 539, 137 DLR $4^{\text {th }} 289$ [Van der Peet] quoted in Delgamuukw, supra note 3 at 1123 .

8 Being Schedule B to the Canada Act 1982 (UK), 1982, c 11, online: <https://www.canlii.org/en/ca/ 
laws/stat/schedule-b-to-the-canada-act-1982-uk1982-c-11/latest/schedule-b-to-the-canada-act1982-uk-1982-c-11.html?autocompleteStr=Const itution\&autocompletePos $=1>$.

921 US 543 (1823).

10 Ibid at 588-89 [emphasis added].

11 [1979] HCA 68.

12 Ibid at 3.

13 [1990] 1 SCR 1075, 70 DLR $\left(4^{\text {th }}\right) 385$ [Sparrow].

14 Ibid at 1103 [emphasis added; citation omitted].

15 Ibid at 1106 citing Noel Lyon, "An Essay on Constitutional Interpretation” (1988) 26 Osgoode Hall LJ 95 at 100.

16 Supra note 1.

17 Taku River, supra note 1 at para 42.

182014 SCC 44, [2014] 2 SCR 256 [Tsilhqot'in].

19 Ibid at para 69.

20 Supra note 3.

21 Delgamuukw, ibid note 3 at 1098.

22 Ibid at 1082.

23 [1985] 2 SCR 387, 24 DLR (4th) 390.

24 Ibid at 401.

$25 R v$ Simon, 134 DLR (3d) 76, 1982 CanLII 2946 (NS SC).

$26 R v$ Syliboy, [1929] 1 DLR 307, 50 CCC 389 (Co $\mathrm{Ct})$.

27 Ibid at 313, quoted in Simon, supra note 25 at 39899.

28 Simon, supra note 25 at 399.

29 Ibid

30 Ibid at 401.

31 The analogy breaks down to the extent that suspended declarations of invalidity are typically suspended for a specified period of time, while the Court has of course not set any deadline for the legitimation of Crown sovereignty.

32 The Court's talk of "federal duty" here is clearly not restrictive in the same way its reference to "federal power" is. Only Parliament, to the exclusion of provincial legislatures, has power pursuant to section 91(24), while section 35 is binding on the Crown broadly speaking, i.e., including Parliament and provincial legislatures, as well as the executive branches of the federal and provincial governments. However, in the wake of Tsilhqot'in largely doing away with the doctrine of interjurisdictional immunity in the context of the Court's section 35 framework, the Court seems to have cleared the way for provincial heads of power to collide with provincial Crown duties under section 35 to almost the same extent as federal power with federal duties.

33 See generally Sparrow, supra note 13.

$34 \mathrm{Ibid}$ at 1109.
35 Part I of Constitution Act 1982, being schedule B to the Canada Act 1982 (UK), 1982, c11, online: $<$ https://www.canlii.org/en/ca/laws/stat/scheduleb-to-the-canada-act-1982-uk-1982-c-11/ latest/schedule-b-to-the-canada-act-1982-uk1982-c-11.html?autocompleteStr $=$ Canadian $\% 20$ Cha\&autocompletePos $=1>$.

36 Van der Peet, supra note 7 at 539.

37 See generally Delgamuukw, supra note 3.

38 At the trial level in Delgamuukw, supra note 3, the plaintiffs, 51 hereditary Chiefs of the Gitxsan and Wet'suwet'en nations, sought "ownership" and "jurisdiction" over 133 distinct territories. By the time the case was before the Supreme Court of Canada, the claim had evolved in important ways. As the Court explained at 1061-62: "On appeal, that original claim was altered in two different ways. First, the claims for ownership and jurisdiction have been replaced with claims for aboriginal title and self-government, respectively. Second, the individual claims by each house have been amalgamated into two communal claims, one advanced on behalf of each nation. However, there were no formal amendments to the pleadings to this effect, and the respondents [British Columbia and Canada] accordingly argue that claims which are central to this appeal are not properly before the Court." The Court, at 1063, "reluctantly" agreed that the second of these two ways the claim was altered caused the respondents "some prejudice" such that the "defect in the pleadings prevents the Court from considering the merits of this appeal."

39 Delgamuukw, supra note 3 at 1123 [citations omitted].

40 Council of the Haida Nation v Minister of Forests, 2000 BCSC 1280 at para 61, [2000] BCTC 924.

41 Haida, supra note 4 at para 10.

$42 \mathrm{Ibid}$ at para 20.

43 Ibid.

$44 \mathrm{Ibid}$ at para 25.

45 Tsilhqot'in, supra note 18 at para 17.

46 Haida, supra note 4 at para 27.

$47 \mathrm{Ibid}$ at para 54.

48 Tsilhqot'in, supra note 18 at paras 77-88.

$49 \mathrm{Ibid}$ at para 80.

50 Rio Tinto Alcan Inc v Carrier Sekani Tribal Council, 2010 SCC 43, at para 44, [2010] 2 SCR 650.

51 See generally Beckman v Little Salmon/Carmacks First Nation, 2010 SCC 53, [2010] 3 SCR 103.

52 See generally Behn $v$ Moulton Contracting Ltd, 2013 SCC 26, [2013] 2 SCR 227.

53 See generally Clyde River (Hamlet) v Petroleum Geo-Services Inc, 2017 SCC 40, [2017] 1 SCR 1069; 
Chippewas of the Thames First Nation $v$ Enbridge Pipelines Inc, 2017 SCC 41, [2017] 1 SCR 199.

54 Supra note 53.

$55 \mathrm{Ibid}$ at paras 4, 43, 52.

56 Haida, supra note 4 at para 45; most recently see Ktunaxa Nation $v$ British Columbia (Forests, Lands and Natural Resource Operations), 2017 SCC 54 at para 83, [2017] 2 SCR 386.

57 Taku River, supra note 1 at para 42. 
